\title{
Taming the "Foreign Tigers"
}

China's anti-trust crusade against multinational companies

\section{Samson Yuen}

\section{(2) OpenEdition}

\section{Journals}

Electronic version

URL: http://journals.openedition.org/chinaperspectives/6587

DOI: 10.4000/chinaperspectives.6587

ISSN: 1996-4617

\section{Publisher}

Centre d'étude français sur la Chine contemporaine

\section{Printed version}

Date of publication: 25 November 2014

Number of pages: $53-59$

ISSN: 2070-3449

\section{Electronic reference}

Samson Yuen, "Taming the "Foreign Tigers" », China Perspectives [Online], 2014/4 | 2014, Online since 01 January 2017, connection on 15 September 2020. URL : http://journals.openedition.org/ chinaperspectives/6587 


\title{
CefC News Analysis
}

\section{Taming the "Foreign Tigers"}

\author{
China's anti-trust crusade against multinational companies
}

\author{
SAMSON YUEN
}

$\mathrm{T}$ hirty years after the launch of the "reform and opening up" policy, China finally implemented its first anti-trust law in 2008, a move lauded by an international law firm as a "tremendous leap forward" that brought the country "squarely into the modern world of antitrust and competition law." (1) Yet, given the law's novelty on Chinese soil, few would have expected China to suddenly begin aggressively enforcing it. Since 2013 Chinese anti-trust regulators have become active in deploying the anti-trust law to initiate probes and impose hefty fines on industry associations, foreign carmakers, eyewear makers, and baby formula manufacturers, meanwhile justifying "dawn raids" on selected firms. Many of their high-profile targets are multinational firms that until then enjoyed a comfortable presence in China. Facing tightened enforcement, foreign companies and chambers of commerce are complaining that regulators are using the law selectively against foreign firms and that investigations lack transparency and respect for the rule of law. Chinese regulators, on the other hand, argue that they are impartial towards domestic and foreign companies, and that they are merely enforcing the anti-trust law in order to create a level playing field for both domestic and foreign companies, benefit Chinese consumers, and bring China closer to the rule of law.

Drawing upon this controversy, this article argues that China's rising antitrust activism is explained by at least two factors. First, the Chinese state is pursuing an industrial policy to encourage indigenous innovation and grow national champions through a palette of regulatory tools. In this context, enforcement of anti-trust law emerges as an important policy tool not only to foster fair competition, but also to serve as a de facto interventionist measure to pressure foreign enterprises to cut prices and oblige them to contribute to the Chinese market and domestic companies. Second, the growing aggressiveness of anti-trust enforcement is possibly fuelled by internal competition and political infighting among the three regulatory bodies, which are all striving to gain political capital under the current uncertain political climate. The article will demonstrate that the resulting complaints from foreign companies and trade associations that they are being selectively targeted are not totally unfounded. To show that the enforcement of the anti-trust law is impartial, Chinese regulators must demonstrate its strength and willingness by striking hard against the monopolistic practices of domestic companies - particularly the powerful state-owned enterprises.

\section{Anti-monopoly law and recent enforcement}

After almost 15 years of drafting, China's Anti-Monopoly Law (AML) was finally promulgated in August 2007 and became effective one year later. ${ }^{(2)}$
Recognised as China's "economic constitution," the AML is China's first comprehensive competition law that oversees issues including merger control, monopoly agreements by multiple firms, and abuse of dominant market position. Its declared purposes include protecting market competition and the legitimate interests of consumers, and above all, protecting public interest and promoting the socialist market economy. The law is enforced by three governmental bodies. The National Development Reform Commission (NDRC), China's top planning agency responsible for the administrative control of the economy, is tasked with overseeing pricing-related monopoly practices while retaining authority under the Price Law (1997). The State Administration of Industry and Commerce (SAIC) takes care of non-pricing-related monopoly practices. The Ministry of Commerce (MOFCOM) is responsible for merger review and monopolisation in foreign trade. Apart from the three enforcement agencies, the State Council has established the Anti-Monopoly Commission. A consultation and coordination body with no substantive enforcement powers, the Commission is responsible for organising, coordinating and supervising AML-related activities.

During the first few years of implementation, Chinese regulators remained largely dormant in enforcing the anti-trust law. Apart from the blocking of Coca Cola's acquisition of Hui Yuan Juice Group by the Ministry of Commerce in 2009 and piecemeal efforts by the NDRC and SAIC to punish local industry associations and companies for monopolistic practices, the focus of investigation remained regional, and the scale of the probes and the fines imposed were small. However, beginning in 2013, as $X_{i}$ Jinping took over the Party leadership position from $\mathrm{Hu}$ Jintao, Chinese regulators turned militant and briskly stepped up efforts to crack down on monopolistic practices. At the start of 2013, the NDRC fined Chinese liquor maker Wuliangye and Kweichow Maotai a record total of 449 million yuan for resale price maintenance. The focus of investigation was subsequently expanded to cover foreign companies. Six Korean and Taiwanese manufacturers of LCD panels were fined 353 million yuan by the NDRC for forming an international price cartel. Then in August 2013, another six manufacturers of baby formula were fined 669 million yuan for resale price maintenance - all but one had foreign investment. In February 2014, the NDRC launched a probe into US mobile chipset maker Qualcomm, a key supplier to the domestic telecommunication sector, on suspicion of overcharging customers. In May 2014, five foreign eyewear manufacturers, including

1. "New Chinese Anti-Monopoly Law," Jones Day, October 2007.

2. Anti-monopoly Law of the People's Republic of China, Ministry of Commerce of the People's Republic of China, August 2007, http://english.mofcom.gov.cn/aarticle/policyrelease/announcement/200712/20071205277972.html (accessed on 31 October 2014). 
Johnson \& Johnson and Nikon, paid a total penalty of 19 million yuan for price manipulation.

A new spate of anti-trust activism primarily targeting foreign firms gained pace as the AML celebrated its sixth anniversary. In early August 2014, as part of anti-trust investigations into foreign automakers, the NDRC paid a surprise visit to the Shanghai office of Daimler AG's luxury auto unit Mercedes-Benz, where officials interrogated senior executives and confiscated computers. About a week later, the agency announced fines on Audi (250 million yuan) and Chrysler (32 million yuan), as well as a total penalty of 1.2 billion yuan on 12 Japanese auto parts makers. At around the same time, the SAIC, which had until then played a less proactive role than the NDRC, came to the fore by conducting two rounds of coordinated "dawn raids" against Microsoft's offices in four Chinese cities for alleged anti-monopoly practices. The Dalian office of Accenture Plc., Microsoft's financial service provider and a foreign consulting firm, was also included in the search.

\section{Antitrust enforcement as part of China's techno-nationalism}

While the intensification of anti-trust investigations demonstrated Chinese regulators' growing confidence in disciplining the market with the $A M L$, its focus on multinational brands also highlighted China's long-standing distrust of foreign companies. Although China's openness to foreign direct investment (FDI) has contributed greatly to its exceptional economic performance, the Chinese government is increasingly wary of the presence of foreign firms as officials aim to build a strong domestic consumption market and capable domestic players. Foreign brands are more often accused of overcharging Chinese customers, who in turn have to pay higher prices for the same products than in other countries. ${ }^{(3)}$ In addition, there are growing concerns over the corrupted practices of foreign businesses operating in China. The Chinese authorities have taken legal action against, for example, executives in the British-Australian mining giant Rio Tinto for industrial espionage and bribery in 2009, (4) and later against executives of the British pharmaceutical company GlaxoSmithKline on allegations of bribing hospitals, doctors, and health institutions to boost sales in 2013. ${ }^{(5}$

Perhaps a more fundamental source of distrust stems from growing concerns that the presence of foreign companies might be harmful to China's state security and national interest. Such concerns are particularly salient in the information and technology sector, which is viewed by the Party leadership as a strategic industry to national development. ${ }^{\left({ }^{6}\right)}$ China has long maintained that the country must reduce reliance on foreign technology suppliers to protect state secrets and promote its domestic technology sector. The proposition was greatly reinforced in 2013 after former US intelligence contractor Edward Snowden leaked classified documents about the US global surveillance programme, which revealed systematic hacking of Chinese targets by the US National Security Agency. China used the incident to lodge protests against US attempts at large-scale cyber attacks, and in return the US Department of Justice indicted five named hackers from China's People's Liberation Army (PLA) for computer hacking and economic espionage. The impact of tension over cyber-espionage was soon felt in relations between the Chinese government and foreign tech firms operating in the country. In late 2013, eight US technology companies, including Microsoft, Cisco, Oracle and Intel, were named and shamed by Chinese state media as the eight "guardian warriors" (bada jingang 八大金刚) collaborating with the US government. A report published by China Economic Weekly, a magazine owned by state mouthpiece People's Daily, listed projects the companies ran with China's government agencies and companies, insinuating attempts to infiltrate Chinese government and business networks and information while implying close links with the US government. ${ }^{(7)}$

Among these "guardian warriors," Microsoft was particularly targeted by the authorities long before the SAIC's "dawn raids" in July and August 2014. Uneasy that dependence on Microsoft products makes it vulnerable to security leaks, the Chinese government has tried shifting to other operating systems and software, such as Linux products, while announcing the development of a home-grown OS. (8) Following an alleged industry complaint, the SAIC began an investigation into Microsoft in June 2013 over issues in compatibility, bundling, and document authentication for its Windows operating system and Office software, on the charge of violating China's antitrust regulations. In May 2014, the Central Government Procurement Center announced that it would forbid the use of the Windows 8 operating system in new government computers in an effort to ensure computer security following Microsoft's plans to retire its Windows XP operating system. ${ }^{\left({ }^{(9)}\right.}$ After the July and August raids, the SAIC even issued a statement "officially warning" Microsoft to obey Chinese law and "not to interfere with or hinder the investigation in any way." (10)

Anxiety with foreign technology further extended to other products, with foreign antivirus software brands, including the US-based Symantec and Russia's Kaspersky, being excluded from the government procurement list of approved software vendors due to fears that they could be turned into tools of cyber-espionage. ${ }^{(11)}$ Even the popular Apple products caught the attention of cautious government authorities. In July 2014, state television CCTV broadcasted a report alleging that the Apple iPhone was a threat to national security because of its location-tracking app, an allegation that Apple Inc. flatly denied. ${ }^{(12)}$ Bloomberg reported that the NDRC and the Ministry of Finance excluded ten Apple products - including the iPad series and MacBook series - from a government procurement list due to security concerns. ${ }^{(13)}$ Perhaps most symbolic of all, China's First Lady Peng Liyuan, who was photographed by the press using an iPhone in June 2013, had switched to a Nubia Z5 mini, a model manufactured by Chinese mobile phone maker ZTE Corporation, in a picture taken in March 2014. ${ }^{(14)}$

3. Adam Jourdan, "Starbucks under media fire in China for high prices," Reuters, 21 October 2013; Kevin Yao and Matthew Miller, "China accuses Qualcomm of overcharging, abusing dominance," Reuters, 19 February 2014.

4. David Barboza, "China Sentences Rio Tinto Employees in Bribe Case," The New York Times, 29 March 2010.

5. "Bribery by GSK China was coordinated at company level: Xinhua," Reuters, 3 September 2013.

6. "China to nurture 7 new strategic industries in 2011-15," Xinhua, 27 October 2010.

7. "Meiguo 'bada jingang' shentou Zhongguo da qidi" (Investigation into America's eight guardian warriors infiltrating China), China Economic Weekly, Vol. 24, 2013, http://paper.people.com.cn/ zgjjzk/html/2013-06/24/content_1259857.htm (accessed on 24 October 2014).

8. Adam Segal, "China has a history of not trusting Microsoft on cybersecurity," Council on Foreign Relations, 30 July 2014; "China targets own operating system to take on likes of Microsoft, Google," Reuters, 24 August 2014.

9. "China excludes Windows 8 from government computers," China Daily, 20 May 2014; Austin Ramzy, "China warns of risks in plan to retire Windows XP," The New York Times, 9 March 2014.

10. Dan Levin, "China Tells Microsoft Not to Interfere With Inquiry," The New York Times, 4 August 2014.

11. Jim Finkle, "Beijing to bar Symantec, Kaspersky anti-virus in procurement: Report," Reuters, 3 August 2014.

12. "Frequent locations could leak state secrets," The Guardian, 14 July 2014.

13. "China said to exclude Apple from procurement list," Bloomberg, 9 August 2014.

14. Amy Li, "Peng Liyuan snapped using an iPhone despite China's war of words with Apple," South China Morning Post, 3 June 2013; Chris Luo, "'Nubia', not iPhone, is Chinese first lady Peng Liyuan's latest choice of smart phone," South China Morning Post, 30 March 2014. 
While China's heightening hostility towards foreign firms might appear to be a new trend, it is in fact the expression of a long-standing techno-nationalism at the heart of China's economic policy-making. Rooted back in the late Qing dynasty in the intellectual discourse of "Chinese learning as substance; Western learning as application" (zhongti xiyong 中体西用), the imperative for China to catch up with the West on science and technology and their linkage to national development were persistent themes throughout the twentieth century. It was expressed during the Mao era through the Party-state's nationalistic efforts to boost indigenous capabilities so as to "overtake Britain and catch up with the US" (chaoying ganmei 超英赶美)， then during the Deng-era of "reform and opening up" in crowning science and technology as one of the four pillars of China's modernisation. These goals were further articulated in national policy-making as China became one of the world's largest economies. Since the mid-2000s, China announced the guiding principle of developing "indigenous innovation" (zizhu chuangxin 自主创新), and enshrined it as a national strategy that put scientific and technological development at the core of rebalancing China's industrial structure and development pattern. ${ }^{(15)}$ The National Mid-to-Longterm Science and Technology Development Plan (MLP) was launched by the State Council in 2006, aiming to build up a leading science-based industry by the year 2020 while helping Chinese companies move up the value chain from producing labour-intensive to high-technology products. ${ }^{(16)}$ The plan identified major research programs for the next 15 years and 27 breakthrough technologies, while vowing to give preferential treatment to Chinese firms bidding for government procurement contracts if they owned the intellectual property rights they would use in the manufacturing process. In 2010, the Central Committee announced a plan to develop seven strategic industries - all of them technology-related - including information technology, energy-saving and environmental protection, energy, biology, high-end equipment manufacturing, materials, and energy cars, vowing to boost fiscal, tax and financial policy support, planning guidance, and major state-level projects to develop them into pillar industries. ${ }^{(17)}$

\section{An industrial policy to push for foreign concessions}

Apart from a strong will to boost the technology sector, the Chinese government has also demonstrated its preference for large firms and companies capable of competing internationally. Scholars have long noted that China's economic policies tend to lean towards large-scale industries in the hope of emulating the developmental pathway of East Asian neighbours such as Japan and South Korea, where state support has played a key role in building globally powerful major corporations. Since the 1990s, under the slogan of "grasping the large and letting the small go" (zhuada fangxiao 抓大放小), Chinese economic policy-makers in the State Council began building national champions by selecting 120 large enterprises groups from sectors considered to be of strategic importance, and nurturing them with a high level of protection and large-scale state financial support. ${ }^{(18)}$ Similar policies were also aimed at focal (zhongdian 重点) large and medium enterprises. ${ }^{(19)}$ Meanwhile, China's state planning system also underwent massive restructuring to become more adaptive to economic transformation and more effective in steering development. (20) Most notably, the NDRC has transformed itself from a central planning authority to a new role as a macro-economic coordinator, and is now responsible for matters such as macro-economic planning (including coordinating the five-year plans), proj- ect and investment approval, resource pricing, and investment fund allocation.

The heightened enforcement of the AML on foreign firms should not be seen in isolation. It appears to be part of a long string of measures that the Chinese authorities have employed to build up and protect domestic industries. It belongs to a large palette of policy tools, including state subsidies, policy support, bank loans, and government procurement programs, meant to support or discipline companies as well as to exclude powerful foreign or unfriendly competitors. It is also consistent with the techno-nationalistic policy requiring foreign firms to contribute to the Chinese economy by developing technology within China, partnering and transferring skills to Chinese firms, or contributing to the Chinese economy as prerequisites to gaining access to domestic customers. As Xu Kunlin, director general of NDRC's price supervision and anti-monopoly bureau, candidly remarked, "given that China is still at the catch-up and overtake stage, industrial policy needs to play its critical role in China's economic development." (21)

One expedient outcome of enforcing AML is to put pressure on companies such that they are willing to cut prices in exchange for a more lenient treatment from regulators. In the case of Mercedes-Benz, for example, the company announced that it would lower prices on more than 10,000 spare parts by an average of $15 \%$ shortly after anti-trust regulators conducted a surprise raid at their Shanghai office. This cut followed a sweeping reduction of prices for repair and maintenance services in the previous month. (22) Similar remedial actions to cut product prices were also taken by Japanese automakers including Toyota, Honda, and Nissan on auto spare parts in response to the spread of anti-trust investigations in the auto industry, and by foreign milk powder makers such as Mead Johnson, Abbott, and Nestlé in response to fines imposed on them. ${ }^{(23)}$ As a result, even though the claimed objective of ensuring fair market competition might not be immediately achieved, price cuts by foreign firms often come first as a direct and immediate consequence of anti-trust enforcement. One reason might have to do with the fact that the NDRC has a long-standing mandate to control prices in the Chinese market. In this context, anti-trust enforcement merely emerges as a new interventionist measure enabling its officials to force firms to slash prices. ${ }^{(24)}$ Admittedly, the result might benefit Chinese companies and domestic consumers paying lower prices for the same products to foreign ven-

15. James McGregor, "China's drive for 'indigenous innovation': A web of industrial policies," U.S Chamber of Commerce Report, February 2011.

16. The full Chinese text of the plan is available at www.gov.cn/jrzg/2006-02/09/content_ 183787.htm (accessed on 20 October 2014); an English translation is available at

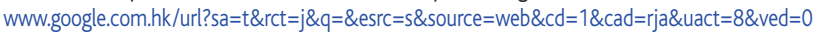
CB0QFjAA\&url=http\%3A\%2F\%2Fsydney.edu.au\%2Fglobal-health\%2Finternationalnetworks\%2FNational_Outline_for_Medium_and_Long_Term_ST_Development1.doc\&ei=QeVEV JTulcbcmgW5p4DoCA\&usg=AFQjCNFSz8ieO3CQYpuGXEAmBFwtffmlEQ\&sig2=Wg8hTvh5CVLSqg3UJpHxLA (accessed on 20 October 2014).

17. "China to nurture 7 new strategic industries in 2011-15," Xinhua, 27 October 2010.

18. Peter Nolan, China and the global economy: National champions, industrial policy and the big business revolution, London, Palgrave Macmillan, 2001.

19. Dylan Sutherland, China's large enterprises and the challenge of late industrialization, New York, RoutledgeCurzon, 2003.

20. Sebastian Heilmann and Oliver Melton, "The Reinvention of Development Planning in China, 19932012," Modern China, Vol. 39, No. 6, 2013, pp. 580-628.

21. "U.S. Firms Wary About China's Free-Market Claims," The Wall Street Journal, 1 August 2014.

22. Samuel Shen and Norihiko Shirouzu, "Daimler's Mercedes-Benz says assisting Chinese authorities in investigation," Reuters, 5 August 2014.

23. "Japanese car makers cut parts prices in China after anti-monopoly probe," Reuters, 9 August 2014.

24. "Unequal before the law?", The Economist, 23 August 2014. 
dors and brands. (25) But other observers believe that forcing popular foreign brands to lower prices might enable them to gain an even greater market share and subsequently harm low-cost entrants. They warned that regulators must consider long-term implications and use more appropriate remedies, such as demanding changes to supplier contracts and relationships, rather than simply pushing for price reductions. ${ }^{(26)}$

Second, anti-trust enforcement serves as a signal to foreign companies that they must add value to China's economic development instead of just profiting from the deep pockets of Chinese consumers, a problem the Chinese authorities are dealing with increasing seriousness. During the course of "reform and opening up," China has always expected foreign companies to transfer technology to domestic firms as an indication of their commitment to China's growth and development. In the automotive industry, for example, foreign carmakers are required to enter into joint ventures with local partners and share technology with them as a prerequisite to selling cars to Chinese customers. The MLP, which was promulgated in 2006, further institutionalised such requirements of technology transfer. It requires foreign companies who wish to compete for government contracts to commit to transferring their proprietary technology and intellectual property to Chinese partners. In the words of a supply chain specialist, "if China doesn't feel it is learning from a business, or a business is just exploiting an advantage it has, it will gently or abruptly stop it (for example with import tariffs or corruption investigations, or more subtly with changes to joint venture ownerships, ease of doing business, or taxation)." (27)

But foreign firms are often offended by this requirement. They fear that their intellectual property and strategy secrets could be leaked to Chinese players during the process of technology transfer. The MLP was even characterised by some of them as "a blueprint for technology theft on a scale the world has never seen," a sharp indication of its unpopularity among multinational firms. ${ }^{(28)}$

Nevertheless, despite protests from foreign companies, China has insisted on viewing technology transfer as an entry ticket to the Chinese market. A 2006 report by the NDRC stated that foreign direct investment had not created enough technological spill-over for the Chinese economy because foreign companies were "abusing" (lanyong 滥用) the protection of intellectual property rights, which would impede possibilities for domestic firms to undertake indigenous innovations. ${ }^{(29)}$ The firmly held position by the Chinese government was even written into the AML. Article 55 states that the Law "shall apply to the conduct of business operators to eliminate or restrict market competition by abusing their intellectual property rights." (30) $\mathrm{Al}$ though references to intellectual property rights are commonly featured in the competition laws of many jurisdictions around the world, in the Chinese context the vaguely defined word of "abuse" in the AML offers huge room for interpretation. Anti-trust regulators are thus equipped with major discretionary powers over how to deploy the AML as disciplinary tools to reward and punish enterprises. To some extent, this turns enforcement of the AML into a legislative tool for administrative purposes so as to bring about technology transfer from firms that are more technologically capable, and discipline those that do not comply with the rule. If firms are willing to meet the terms set out both formally and informally by Chinese regulators, they could be exempted from probes or given lighter consequences if they are under investigation. In fact, Chinese anti-trust regulators have the ability to terminate investigations without imposing fines provided that the violating party promises to change its practices, and they also have the discretionary power to adopt a more flexible (while also arbitrary and opaque) approach in imposing penalties. This perhaps explains why Qualcomm announced in July 2014 that it would commit to a $\$ 150$ million "strategic venture fund" that invests in Chinese technology start-up companies across all stages, especially in the following areas: Internet, e-commerce, semi-conductor, education and health. ${ }^{(31)}$ Other companies sought to gain access to the Chinese market by choosing a compliant strategy from the very beginning. Linkedln, a social networking platform for professionals and executives, is a notable example of foreign firms seeking to play by local rules. As a wellpositioned player in making Chinese employment market more efficient and thus stimulating the economy, LinkedIn is likely to enjoy more autonomy in navigating the Chinese market given its active compliance. (32)

\section{Political infighting between Chinese regulators}

Another thrust of anti-trust activism is generated by a different set of dynamics: the internal strife between Chinese anti-trust regulators. Jamil Anderlini, Beijing bureau chief for Financial Times, brought up this point, suggesting that the anti-trust campaign that has been primarily led by the NDRC "has more to do with institutional infighting and internal political turf wars than a master plan to exclude foreign investors from the country." (33) As Anderlini pointed out, the reason that the NDRC was increasingly aggressive in enforcing the AML was that the NDRC has become "one of the biggest institutional losers in the administrative reforms introduced by Mr. Xi [jinping]." Arguably one of China's most powerful bureaucracies, the NDRC was once the country's top economic planning agency that oversaw the process of licensing, planning, and approval for investment projects and five-year plans. However, these powers have been significantly curtailed since Xi took power, and as a result of the streamlining of government and the delegation of responsibility to the lower levels (jianzheng fangquan 简政放权) as well as the shortening or cancellation of administrative approval processes. After the Third Plenum of the $18^{\text {th }}$ CPC Central Committee, President Xi took personal charge of a newly set up small leading group for deepening reform, tasked with overseeing national economic strategy under the pledge to give a "decisive role" to market forces in allocating resources. This leading group further ate into the power of the State Council and the NDRC in managing the country's economic affairs. These changes, argued Anderlini, contributed to the decline of the NDRC's standing within the state bureaucracy, together with its ability to "seek rents and procure bribes."

25. "China using antimonopoly law to pressure foreign businesses," The Wall Street Journal, 4 August 2014.

26. "David Hoffman on anti-monopoly investigations into foreign companies in China," The New York Times, 11 August 2014; "Unequal before the law?", The Economist, 23 August 2014.

27. Roy Williams, "Has doing business in China just got too risky?", Financial Times, 11 August 2014.

28. David Abraham and Meredith Ludlow, "China's New Plan for Economic Domination," The Atlantic, 18 May 2011.

29. "Fagaiwei youguan fuzeren jiu liyong waizi shiyiwu guihua da jizhewen" (Spokesman from the NDRC responding to journalists regarding the use of foreign investment in the 11th five-year plan), Sina, 9 November 2006, http://finance.sina.com.cn/roll/20061109/15451031677.shtml (accessed on 24 October 2014).

30. Anti-monopoly Law of the People's Republic of China, op. cit.

31. Announcement by Qualcomm, 23 July 2014, www.qualcomm.com/news/releases/2014/07/23/ qualcomm-commits-150-million-strategic-venture-fund-china (accessed on 24 October 2014); Andrew Jacobs, Chris Buckley, and Nick Wingfield, "With Microsoft in Sights, China Starts to Squeeze U.S. Tech Companies," The New York Times, 28 July 2014.

32. "To reach China, LinkedIn plays by local rules," The New York Times, 6 October 2014

33. Jamil Anderlini, "Multinationals fret as China's antimonopoly probes intensify," Financial Times, 6 August 2014 
To regain importance as well as to adhere to Xi's vision of market reforms, the NDRC must transform itself from a cumbersome economic planning agency into a lean macro-economic coordinator and regulator that is able to take up a more relevant role under an increasingly market-driven Chinese economy. ${ }^{(34)}$ One possible direction for revamping the NDRC is to enhance the agency's role as the country's major anti-trust regulator, for which it is legitimately positioned. ${ }^{(35)}$ This helps explain why the NDRC has turned proactive in enforcing anti-trust regulations in the past two years. Targeting well-known foreign brands will be effective in highlighting the NDRC's new role because it is likely to make good headlines, and such cases are easy to present as showing that the NDRC is serving the interests of Chinese consumers. In light of the NDRC's increasingly proactive role in punishing foreign firms for anti-trust violations, the fact that the SAIC began to flex its muscle by initiating probes and raids on Microsoft spurred speculation that the agencies are jockeying for position in the midst of growing debate over whether to have a single agency rather than three responsible for enforcing the Anti-Monopoly Law. ${ }^{(36)}$ In December 2013, NDRC anti-trust chief Xu Kunlin said in China Daily that he favoured merging the three anti-trust agencies, which have overlapping responsibilities, into one government enforcement body. He also quoted the opening phrase - "The empire, long divided, must unite" - from the Romance of the Three Kingdoms, a classic Chinese novel based on the power struggles of three warring states fighting for dominance in the post-Han dynasty. (37) If Xu's ambition was indeed to turn his agency into the country's sole anti-trust body, then the SAIC's highprofile move against Microsoft is at least one major obstacle in making his ambition come true.

\section{Complaints from abroad and state responses}

Regardless of the motivation and dynamics behind recent anti-trust probes, the scale and intensity were sufficient in creating shockwaves across the community of foreign firms operating in China. Two recent surveys conducted by US business associations illustrated growing concerns that US companies were being targeted by Beijing in the anti-trust crusade. One conducted by the US-China Business Council showed that $86 \%$ of its member companies are concerned about Beijing's anti-trust enforcement, with $30 \%$ fearing the law will be used against them. They are worried that the AML was passed more to protect China's domestic industry than to promote fair competition, and that the law is used to force foreign companies to slash prices. ${ }^{(38)}$ Another one, done by Beijing's American Chamber of Commerce, found that $60 \%$ of respondents believe that foreign business is less welcome in China than before, up from $41 \%$ last year. Meanwhile, nearly half of the respondents said they have been targeted in either the anti-monopoly or anti-corruption campaigns. ${ }^{(39)}$ Back in April 2014, the US Chamber of Commerce sent a private letter to Secretary of State John Kerry and Treasury Secretary Jacob Lew. The letter urged Washington to take a tough stance against Beijing on the issue of anti-trust enforcement because the "Chinese government has seized on using the AML to promote Chinese producer welfare and to advance industrial policies that nurture domestic enterprises." (40) In a similar vein, the European Union Chamber of Commerce in China complained that "foreign companies are being disproportionately targeted." (41) Observers complained that the investigations often lack due process and transparency, and that regulators sometimes use threats and even torture in forcing executives to admit wrongdoing. ${ }^{(42)}$ Moreover, results of investigations and penalties are usually opaque and incompletely disclosed, or only disclosed after a considerable period of time. ${ }^{(43)}$ All this has further stirred up the worries of foreign companies over their long-term operations in China. Coincidentally, there has been the recent decline in the amount of foreign direct investment in China, which might well be a reflection of these worries. ${ }^{(44)}$

Chinese state media responded to these growing fears by saying that critics had misunderstood the nature of China's antitrust investigations. In an article entitled "Why is the US making a fuss over China's antitrust campaign?", People's Daily argued that China's anti-trust investigations do not justify such over-reaction from the US, pointing out that anti-monopoly laws and regulations have been and will be applied equally to foreign and home-grown companies. ${ }^{(45)}$ Quoting figures from a progress briefing jointly held by the three anti-regulators, the article stated that of the 335 companies and industry associations investigated by the NDRC, only 33 are foreign. It added that recent probes into Microsoft and Tetra Pak make up only two out of the 39 cases filed under the SAIC, the rest of which involved Chinese companies and associations. The article concluded by saying that China is not the only country enforcing anti-trust laws and regulations, pointing to the fact that the US Department of Justice launched nearly 100 investigations in 2013 and thus criticising their "double standard" in view of similar actions in China. Chinese regulators elsewhere said they have also targeted domestic giants such as China Telecom and China Unicom for anti-monopoly practices in the broadband market as an example of fairness to both foreign and domestic companies - even though the cases have failed to result in any tangible outcomes, possibly due to pressures from higher-ups. ${ }^{(46)}$

\section{Is anti-trust enforcement fair-handed?}

While foreign companies might make up of a small proportion of antitrust investigations in terms of the number of cases filed, it is an opposite case for the amount of fines imposed on them by Chinese regulators. As Graph 1 shows, almost $80 \%$ of the total fines reported by the NDRC were imposed on foreign companies, even though they only make up around $10 \%$ of the investigations. The average amount of fines imposed on foreign companies violating anti-trust regulations is around 80 million yuan per company, eight times the amount imposed on domestic firms.

34. Peter Martin, "The Humbling of the NDRC: China's National Development and Reform Commission Searches for a New Role Amid Restructuring," Jamestown Foundation China Brief, Vol. 14, No. 5, March 2014

35. Michael Martina and Benjamin Lim Kang, "China's state planning body grows more assertive as revamp looms," Reuters, 2 March 2014.

36. "Pandian fanlongduan anli: zhengshe chushou, sanda zhifa jigou yuequan?"(Recapping anti-monopoly cases: fighting to strike, are the three enforcement authorities overstepping beyond responsibility?), The Paper, 9 August 2014, available at www.thepaper.cn/newsDetail_forward_ 1260550_1 (accessed on 22 October 2014)

37. "China's antitrust investigators 'using threats and bullying' against companies," South China Morning Post, 16 September 2014.

38. "U.S. companies fear growing protectionism in China," Business Week, 3 September 2014.

39. Ibid.

40. "China's latest anti-trust probes receive protectionism concerns," Reuters, 7 August 2014.

41. "Unequal before the law," The Economist, 23 August 2014.

42. "China's antitrust investigators 'using threats and bullying' against companies," art. cit.

43. "China antitrust regulator discloses penalties to boost transparency," South China Morning Post, 8 September 2014.

44. "Foreign Direct Investment in China Declines," The Wall Street Journal, 17 June 2014.

45. "Why is the US making a fuss over China's antitrust campaign?", People's Daily, 22 September 2014.

46. "Unequal before the law," The Economist, 23 August 2014. 


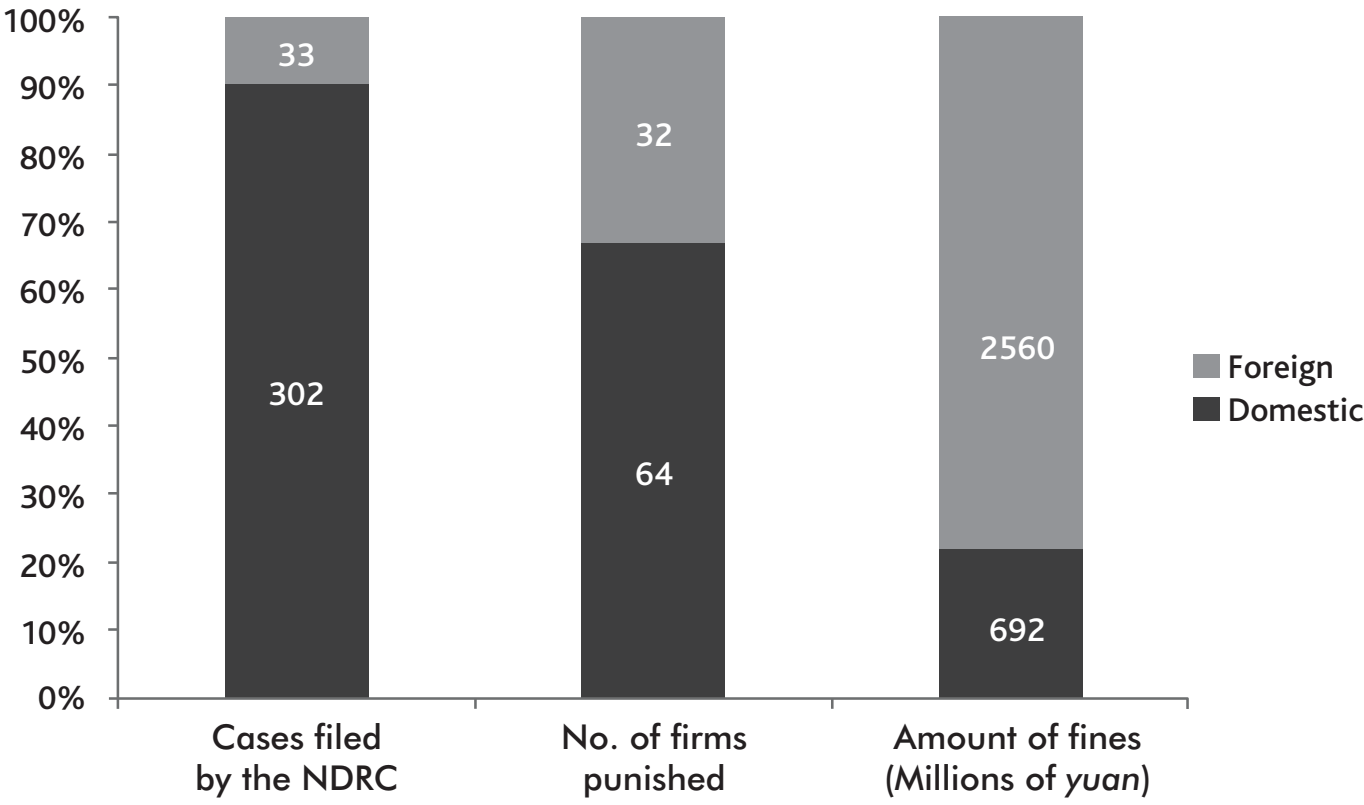

Source: National Development Reform Commission

In addition, there have been a number of eyewitness accounts describing "administrative intimidation tactics" used by regulators during anti-trust investigations. One report recounted how lawyers from foreign firms were "gathered in a room" and warned by an NDRC official "not to challenge its inquiries or risk facing extreme penalties." Others are told not to bring in lawyers, challenge investigations in court, or involve their respective governments or chambers of commerce. ${ }^{(47)} A$ Reuters report called this "a culture of intimidation under the leadership of Director General Xu Kunlin," quoting lawyers who said that the antitrust bureau has used "widespread behind-the-scenes tactics - from personal threats to forced apologies and brow beatings" - to enforce anti-monopoly laws and regulations. It even compared these tactics to those used by Red Guards during the Cultural Revolution, which is typically a serious accusation of mob-like activity. ${ }^{(48)}$ Even domestic observers are questioning the legality of anti-trust investigations. Liu Xu, a Chinese legal researcher, raised nine problems with the campaign in a three-part article using the NDRC's probe into Qualcomm as an example. These problems include enforcing the law beyond the agency's jurisdiction, using the wrong legal clauses, lack of evidence, restricting the right to defence and the right to hearing, lack of information disclosure, excessive discretion in dishing out administrative punishment, doubts over the agency's independence, selective and subjective enforcement, and the idling of the Anti-Monopoly Commission. ${ }^{(49)}$

All of this suggests that fair treatment of domestic and foreign companies by Chinese anti-trust regulations is at least a questionable claim. To defend this claim, Chinese regulators must show not just fairness in their willingness or attempts to investigate both domestic and foreign players, but also fairness and equal treatment in the process and result of the investigations. Chinese authorities must also demonstrate that they are willing to pursue powerful domestic players. Observers are already questioning why anti-trust investigations are not targeting the powerful and well-connected stateowned enterprises (SOEs), especially as China has embarked on a plan to consolidate around 150 SOEs into between 80 and 100 big firms. (50) SCMP chief editor Wang Xiangwei, for example, asked in a Twitter posting whether the anti-trust probe will take on the "obvious monopoly by PetroChina and Sinopec." (51) Although the principle of safeguarding public interests listed in the AML might well become a layer of protection for SOEs, Chinese regulators must show their real teeth by removing the protective coat and striking at all monopolistic practices, whether they are committed by foreign or domestic firms.

\section{Conclusion}

Over the past two years, China's anti-trust regulators have been gradually building up their confidence in enforcing the six-year old Anti-Monopoly Law. By launching high-profile probes into a score of foreign companies and imposing exorbitant penalties on them, China is demonstrating its growing intolerance of foreign malpractice in China and an increasing willingness to discipline market players in accordance with domestic regulations. However, as this article shows, anti-trust enforcement has been inseparable from motives and dynamics other than ensuring free competition. It is fuelled by a deep-rooted techno-nationalistic sentiment to link science and technology development to national well-being, to protect national security, and to nurture domestic technology firms into some of the world's best. Anti-trust measures are among a range of regulatory - or even interventionist - measures to pressure foreign firms to cut prices and make them contribute more tangibly to the Chinese economy from China's perspective, such that domestic firms can benefit. Seen in this light, the enforcement of the AML reflects how the Chinese state is using its visible hands (kandejian de shou 看 得见的手) in combination with the invisible hands of the market (kanbujian de shou 看不见的手). ${ }^{(52)}$ In doing so, anti-trust regulators are not "regula-

\footnotetext{
47. Ibid.

48. '"Mr. Confession' and his boss drive China's antitrust crusade," Reuters, 15 September 2014.

49. "Pandian fanlongduan anli: zhengshe chushou, sanda zhifa jigou yuequan?", art. cit.

50. "SOE trim-down collides with antitrust law," The Economic Observer Online, 4 August 2008.

51. George Chen, "Antitrust or anti-foreigner in China?", South China Morning Post, 11 August 2014.

52. "Visible and invisible hands," China Daily, 30 May 2014
} 
tors" in the traditional sense, but regulators who play a much more proactive role in shaping the course of national development, and who have their own private interests and calculations to survive and perform in the political system.

While it is indeed inaccurate to say that foreign firms are being disproportionally targeted in investigations, it would be equally inaccurate to claim that regulatory authorities have given fair treatment to foreign and domestic companies alike, and that the investigation process is transparent and in accordance with the rule of law. To demonstrate the case otherwise, anti-trust regulators must not only uphold legal procedures during investigations and enhance transparency on the whole process; they must also step out of their comfort zone to toughen up on the powerful state-owned giants that have obvious monopolistic traits. Doing so, however, is not just a politically demanding task in the face of powerful interest groups in the Party-state bureaucracy, but also one that ironically conflicts with the ambition of the NDRC to become China's largest and only anti-trust regulator.

ISamson Yuen is a PhD student in politics at the University of Oxford and is a research assistant at the CEFC (samson.yuen@sant.ox.ac.uk).

CEFC News Analysis is compiled from the CEFC's fortnightly selection of Press Highlights, available at www.cefc.com.hk. 